\title{
Mechanisms of Tolbutamide-Stimulation of Pancreatic B Cells - A Reply
}

\section{Dear Sir,}

There is no doubt that the mechanisms of action of sulphonylureas on pancreatic B cells are still incompletely understood. The letter by Dr. Malaisse and his colleagues reinforces one conclusion of my article [1]: "The basis of the interaction between glucose and tolbutamide, not investigated here, remains to be clarified".

The following points in their letter deserve some comments:

1) The proposal that tolbutamide directly interferes with $\mathrm{Ca}^{2+}$ transport in $\mathrm{B}$ cells is interesting, but difficult to evaluate adequately since the reference paper is not available yet [2]. From abstract reports $[3,4]$, it can be appreciated, however, that Malaisse et al. ascribe the insulinotropic activity of sulphonylureas to a $\mathrm{Ca}^{2+}$-ionophoretic capacity, similar to that of the classical $\mathrm{Ca}^{2+}$-ionophore A23187. Such an interpretation does not seem compatible with the evidence that tolbutamide does not penetrate B cells [5].

2) In the absence of glucose stimulation, tolbutamide decreases $\mathrm{Rb}^{+}$efflux from islet cells [6]. This original report has been confirmed [7] and extended [1]. Furthermore, recent electrophysiological evidence [8] strongly suggests that the reduction in $\mathrm{K}^{+}$permeability is involved in the depolarization of $\mathbf{B}$ cells by tolbutamide. It also shows that increasing the concentration of extracellular $\mathrm{Ca}^{2+}$ during tolbutamide stimulation tends to repolarize $B$ cells and replaces the continuous electrical activity by regular bursts. These observations [8] and the measurements of insulin release, $\mathrm{Ca}^{2+}$ uptake and $\mathrm{Rb}^{+}$efflux [1] would be difficult to explain, if tolbutamide were acting simply as a $\mathrm{Ca}^{2+}$-ionophore.

3) In the presence of a stimulatory concentration of glucose $(8.3 \mathrm{mmol} / \mathrm{l})$, tolbutamide surprisingly produces a short-lived increase in $\mathrm{Rb}^{+}$efflux. Such an effect, however, is not specific to sulphonylureas. Potentiation of glucose-stimulated $(7 \mathrm{mmol} / \mathrm{l})$ insulin release by $2 \mathrm{mmol} / \mathrm{l}$ theophylline is also attended by an initial and transient rise in the rate of $\mathrm{Rb}^{+}$efflux [9]. If one a priori rules out that such a brief event might occur in non-B cells, the most plausible explanation is that it reflects activation of the $\mathrm{K}^{+}$permeability of $\mathrm{B}$ cells by a rise in intracellular $\mathrm{Ca}^{2+}[10]$. By no means, however, is it sufficient to exclude activation of voltage-dependent $\mathrm{Ca}$ channels, the permeability of which depends on the membrane potential and not on the $\mathrm{K}^{+}$permeability per se. Although the electrical effects of tolbutamide on B cells stimulated by glucose have been paid little attention, so far, preliminary data [11] suggest that the drug increases the duration of the phases of depolarization induced by $11 \mathrm{mmol} / \mathrm{l}$ glucose.

No explanation is completely satisfactory for all effects of tolbutamide on B cells; their understanding obviously requires further investigation. I suggest, however, that to avoid unnecessary controversies, more attention be paid to the relevant concentrations of the drug. Thus, it has become clear now $[1,8]$, that concentrations of tolbutamide similar to those found in vivo produce, in B cells, ionic, electrical and secretory effects, different from the supposedly "classical" effects described with the high concentrations $(>50 \mu \mathrm{g} / \mathrm{ml}$ ) commonly used in vitro.

Yours sincerely,

J. C. Henquin

\section{References}

1. Henquin JC (1980) Tolbutamide stimulation and inhibition of insulin release: studies of the underlying ionic mechanisms in isolated rat islets. Diabetologia 18: 151-160

2. Anjaneyulu R, Anjaneyulu K, Couturier E, Malaisse WJ (1980) Opposite effects of hypoglycemic and hyperglycemic sulfonamides upon ionophore-mediated calcium-transport. Biochem Pharmacol (in press)

3. Malaisse WJ, Devis G, Hutton JC, Somers G (1977) Effect of insulinotropic agents on $\mathrm{Ca}^{2+}$ translocation in an artificial system. Diabetes 26: 407 
4. Couturier E, Malaisse WJ (1980) Ionophoretic capacity of hypoglycemic sulphonylureas. Proceedings of the 14th annual Meeting of the European Society for Clinical Investigation, $p$ 8, Abstract No. 43

5. Hellman B, Taljedal I-B (1975) Effects of sulfonylurea derivatives on pancreatic B cells. In: Hasselblatt A, von Bruchausen F (eds) Insulin II. Springer, Berlin Heidelberg New York, p 175-194

6. Henquin JC (1977) Possible mechanisms of tolbutamide acute stimulation and secondary inhibition of insulin release by perifused rat islets. Diabetologia 13: 401

7. Boschero AC, Malaisse WJ (1979) Stimulus-secretion coupling of glucose-induced insulin release. XXIX. Regulation of ${ }^{86} \mathrm{Rb}^{+}$ efflux from pancreatic islets. Am J Physiol 236: E139-E149

8. Meissner HP, Preissler M, Henquin JC (1980) Possible ionic mechanisms of the electrical activity induced by glucose and tolbutamide in pancreatic B cells. In: Waldhäusl W (ed) Dia- betes 1979, Proceedings of the 10th Congress of the IDF. Excerpta Medica, Amsterdam, p 166-171

9. Henquin JC (1980) Metabolic control of potassium permeability in pancreatic islet cells. Biochem J 186: 541-550

10. Henquin JC (1979) Opposite effects of intracellular $\mathrm{Ca}^{2+}$ and glucose on $\mathrm{K}^{+}$permeability of pancreatic islet cells. Nature 280: $66-68$

11. Cook D, Crill W, Porte D (1979) Do tolbutamide and elevated potassium have the same mechanism of action on islet cells? Diabetes 28: 403

Dr. J. C. Henquin

Unité de Diabète et Croissance

University of Louvain, UCL 54.74

B-1200 Brussels

Belgium

\section{Haematocrit, Glycosylated Haemoglobin and Diabetic Microangiopathy}

\section{Dear Sir,}

Poorly controlled diabetics tend to have higher $\mathrm{HbAl}$ values than well-controlled diabetics and nondiabetics [1]. It has been suggested that glycosylated haemoglobin, by causing a shift in the oxygen dissociation curve [2], may lead to local tissue hypoxia and so stimulate erythropoietin production. Ditzel and Standl [3] have suggested a role for tissue hypoxia in the evolution of microvascular diabetic complications. Not only could local hypoxia be damaging by itself, it could also, by the mechanism outlined induce polycythaemia, increase blood viscosity and so impair flow in the microcirculation.

In a recent paper Graham et al. (Diabetologia 18: 205,1980 ) claimed that diabetics tend to have a relative polycythaemia which correlates with their $\mathrm{HbAl}$ values when compared with non-diabetics. We would like to raise several points. First, although retinopathy and nephropathy often occur together and are therefore both considered to be examples of microangiopathy, it is not yet proven that they have an identical aetiopathogenesis. Secondly, when severe nephropathy coexists with retinopathy blood analysis may reveal a normocytic normochromic anaemia. When assessing the degree of polycythaemia we agree that red cell mass is the most accurate method currently available but we feel that as a simpler method the packed cell volume (PCV) or haematocrit is a more useful index of polycythaemia than the red cell count which was the only parameter used by Graham et al. Blood flow is partly dependent on viscosity which is directly related to the PCV [4].

We have analysed the PCV and $\mathrm{HbAl}$ values in a series of Type 1 (insulin-dependent) diabetics with and without microangiopathy divided into the following groups; Group 1 (22 patients) without any complications; Group 2 (26 patients) proliferative retinopathy without evidence of nephropathy, serum creatinine $<0.10 \mathrm{mmol} / \mathrm{l}$; Group 3 ( 8 patients) proliferative retinopathy with biochemical evidence of early nephropathy, serum creatinine $>0.10 \mathrm{mmol} / \mathrm{l}$; Group 4 (5 patients) proliferative retinopathy with overt nephropathy serum creatinine range $0.16-0.83 \mathrm{mmol} / \mathrm{litre}$. The patients with and without complications had a similar age distribution and duration of diabetes.

There was no difference in the PCV between the patients without complications and those with proliferative retinopathy alone (Group 1: mean PCV $0.42 \pm 0.04$; Group 2: mean PCV $0.41 \pm 0.04$ ). In addition, there was no significant difference in haemoglobin values between the retinopathy only group (mean $\mathrm{Hb} 13.7 \pm 1.6 \mathrm{~g} / 100 \mathrm{ml}$ ) and the patients with nephropathy (Groups $3+4$ : mean $\mathrm{Hb} 12.8 \pm 2.1 \mathrm{~g} / 100 \mathrm{ml}$ ) although the $\mathrm{Hb}$ tended to 